\title{
PENGARUH PENAMBAHAN EFFECTIVE MICROORGANISMS-4 SEBAGAI BIOCATALYST TERHADAP PENINGKATAN KONSENTRASI AMMONIUM SEBAGAI SUMBER PUPUK
}

\author{
Eko Ariyanto $^{1 *}$, Shanti Mayasari ${ }^{2}$, Dian Kharismadewi ${ }^{3}$ \\ ${ }^{1}$ Program Studi Teknik Kimia, Fakultas Teknik, Universitas Muhammadiyah Palembang, \\ Jalan A. Yani 13 Ulu Palembang, Indonesia - 30263 \\ 1,2,3 Program Studi Magister Teknik Kimia, Program Pascasarjana, Universitas \\ Muhammadiyah Palembang, Jalan A. Yani 13 Ulu Palembang, Indonesia - 30263 \\ *e-mail: eko_ariyanto@um-palembang.ac.id
}

\begin{abstract}
Organic waste processing in the form of vegetable residues can be processed anaerobically. To accelerate the rate of degradation of organic waste, Effective Microorganisms- 4 can be added to the anaerobic process, which can produce high $\mathrm{NH}_{4}$ by-products. This study aimed to determine the effect of EM-4 on the production of $\mathrm{NH}_{4}$ in the anaerobic process of organic waste. The kinetic analysis of the organic waste degradation process was also investigated. The research methodology was carried out in a batch anaerobic reactor. The results showed that increasing EM4 concentration from 0 to $50 \mathrm{ml}$ can increase the concentration of $\mathrm{NH}_{4}$ and be stable after the addition of more than $50 \mathrm{ml}$. The kinetic value $(\mathrm{k})$ of the organic waste degradation was 0.0750 day- 1 for no addition of EM-4 $(0 \mathrm{ml})$, and the value of $k$ increased after adding EM-4. The implication of this research is to provide a solution to reduce pollution of organic waste, and the resulting $\mathrm{NH}_{4}$ can be used as a source of plant fertilizer.
\end{abstract}

Keywords: effective microorganisms-4, vegetable residues, ammonium, anaerobic process

\begin{abstract}
ABSTRAK
Pengolahan sampah organik berupa sisa sayuran dapat diproses secara anaerobik. Agar proses degradasi sampah organik tersebut berjalan dengan cepat, maka diperlukan bantuan Effective Microorganisms-4 yang akan menghasilkan produk samping yaitu konsentrasi $\mathrm{NH}_{4}$ yang tinggi. Tujuan penelitian ini adalah mengetahui pengaruh EM-4 terhadap produksi $\mathrm{NH}_{4}$ pada proses anaerobik sampah organik. Dan analisa lebih lanjut yaitu kinetika proses degradasi sampah organik terhadap peningkatan konsentrasi $\mathrm{NH}_{4}$. Metodologi penelitian yang dilakukan adalah secara batch menggunakan reaktor anaerobik. Hasil penelitian menunjukkan bahwa semakin meningkatnya konsentrasi EM-4 dari 0 sampai $50 \mathrm{ml}$ maka konsentrasi $\mathrm{NH}_{4}$ yang dihasilkan semakin besar. Setelah penambahan lebih dari $50 \mathrm{ml}$ tidak terjadi peningkatan produksi $\mathrm{NH}_{4}$. Nilai konstanta kinetika laju degradasi sampah organik tanpa penambahan EM-4 didapat 0,0750 hari ${ }^{-1}$. Dan nilai konstanta kinetika meningkat setelah ditambahkan EM-4 sebagai biokatalis. Implikasi dari penelitian ini adalah memberikan solusi untuk mengurangi pencemaran sampah organik dan $\mathrm{NH}_{4}$ yang dihasilkan dapat dijadikan sumber pupuk tanaman.
\end{abstract}

Kata Kunci: effective microorganisms-4, sampah organik, ammonium, proses anaerobik. 


\section{PENDAHULUAN}

Pengolahan sampah organik secara umum dapat dilakukan melalui proses anaerobik digestif. Anaerobik digestif menghasilkan biogas yang mengandung metana $\left(\mathrm{CH}_{4}\right)$ yang dapat digunakan untuk pembangkit energi. Selain itu produk samping dari proses anaerobik pada sampah organik adalah cairan dan lumpur dengan konsentrasi $\mathrm{NH}_{4}$ yang tinggi (Foereid, Szocs, Patinvoh, \& Horváth, 2021; Sogn et al., 2018).

Lamanya waktu yang dibutuhkan pada proses degradasi pengolahan sampah organik merupakan salah satu faktor yang harus diupayakan agar proses anaerobik dapat berlangsung dengan cepat dan efisien. Salah satu solusi untuk mempercepat proses degradasi bahanbahan organik yang bersumber dari sampah, maka dibutuhkan mikroorganisme yang dapat mencerna selulosa, pati, gula, lemak dan protein dalam sampah organik. Dari penelitian yang dilakukan oleh Prayitno, Rulianah \& Nurmahdi (2020) menunjukkan bahwa semakin banyak bakteri indigeneous maka waktu proses dapat dipersingkatn dan produksi gas metan yang dihasilkan semakin banyak.

Dalam penelitian ini mikroorganisme adalah Effective Microorganism 4 (EM4). Bakteri EM-4 mampu mempercepat proses pengolahan sampah organik (Haerun, Mallongi, \& Natsir, 2018; Hidayat, Hidayati, \& Utomo, 2012). Bakteri EM-4 juga mampu menurunkan kadar BOD dan COD pada sampah (Haerun et al., 2018). EM-4 adalah larutan yang didalamnya terkandung berbagai macam mikroorganisme seperti Lactobacillus casei, Saccharomyces cerevisiae, dan Rhodopseudomonas palustris) yang dapat mencerna selulosa, pati, gula, lemak dan protein dalam sampah organik (Nurjuwita, Sasongko, Hartanto, \& Purwanto, 2021).
Menurut penelitian yang dilakukan oleh Nurjuwita et.al., (2021) bahwa penambahan EM-4 ini dapat mengurangi fase lag dari mikroorganisme dan membuat proses degradasi senyawa organik kompleks menjadi lebih singkat dan efisien, sehingga dapat meningkatkan produksi biogas.

Peningkatan konsentrasi EM-4 yang ditembahkan ke dalam proses anaerobik sampah organik akan meningkatkan $\mathrm{NH}_{4}$ yang dihasilkan akan tetapi jika penambahan EM-4 yang berlebih akan berdampak negatif terhadap pertumbuhan mikroba karena jumlah mikroorganisme tidak sebanding dengan jumlah sumber makanan yang tersedia. Sehingga terjadi persaingan antar microorganism dalam mendapatkan sumber makanan (Siswati, Theodorus, \& Eko, 2009).

Beberapa penelitian sebelumnya masih sedikit sekali penelitian yang menganalisa pengaruh mikroorganisme EM-4 terhadap proses produksi $\mathrm{NH}_{4}$. Sebagaimana diketahui bahwa $\mathrm{NH}_{4}$ adalah sumber nutrisi bagi tanaman. Adapun tujuan dari penelitian ini adalah untuk mengetahui pengaruh EM-4 terhadap produksi $\mathrm{NH}_{4}$ pada proses anaerobik sampah organik. Selian itu juga dianalisa kinetika proses anaerobik sampah organik dengan tanpa dan penembahan EM-4.

\section{BAHAN DAN METODE}

\section{Bahan}

Bahan utama dalam penelitian ini adalah sampah organik dan larutan EM-4. Sampah organik berasal dari sampah pasar berupa sayur - sayuran sisa hasil proses jual beli yang telah dibuan di Tempat Pembuangan Sampah.

Larutan EM-4 yang digunakan dalam penelitian ini mengandung bakteri fermentasi dari genus Lactobacillus dan Saccharomyces yang di produksi oleh PT. Songgolangit Persada Jakarta (Gambar 1). 


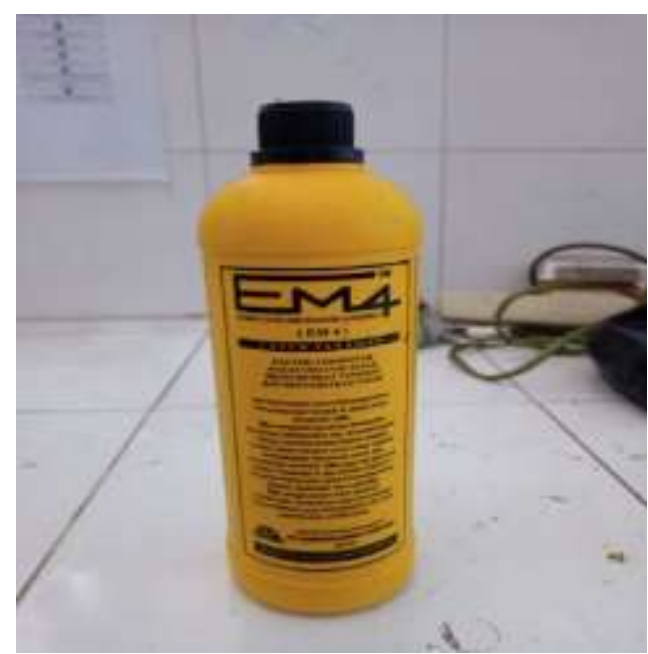

Gambar 1. Larutan EM-4

\section{Metode Peralatan}

Peralatan yang digunakan dalam penelitian adalah anaerobik reaktor yang digunakan untuk memproses sampah organik. Adapun skema peralatan dapat dilihat pada Gambar 2 sebagai berikut.

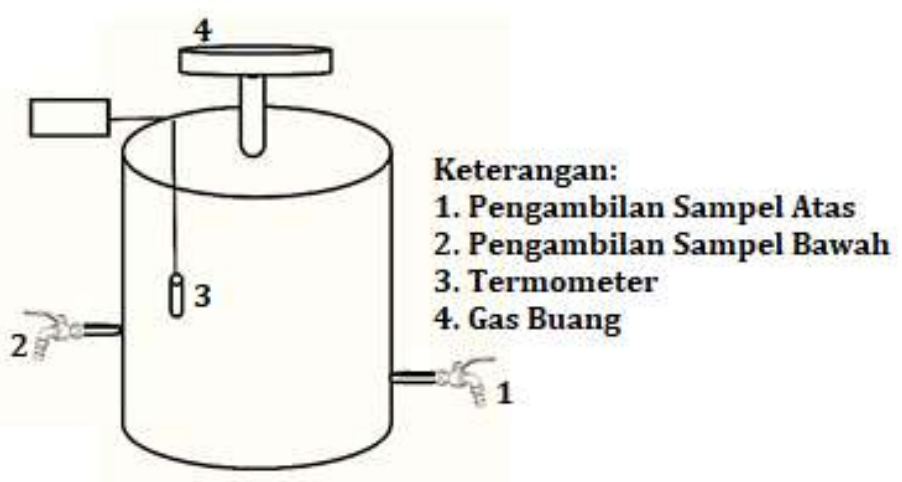

Gambar 2. Skema Alat Anaerobik

\section{Metode Persiapan Lar. Starter EM-4}

Larutan EM-4 disiapkan 30, 50, 70 dan $100 \mathrm{ml}$ dan ditambahkan air sehingga volumenya menjadi 1 L. Kemudian ditambahkan kotoran sapi sebanyak 500 gram, lalu diaduk hingga rata. Untuk tanpa penambahan EM-4, kotoran sapi 500 gram diaduk di dalam 1 liter air. Larutan starter tersebut kemudian disimpan selama 4 hari pada ruang temperatur. Sehingga jumlah mikroorganisme akan meningkat dan proses degradasi senyawa organik kompleks juga akan optimal. Larutan starter tersebut dianalisa konsentrasi $\mathrm{NH}_{4}$ menggunakan spectrophotometer Hanna 83300. Pengukuran $\mathrm{NH}_{4}$ dilakukan untuk mengidentifikasi konsentrasi $\mathrm{NH}_{4}$ pada larutan starter.

Langkah selanjutnya adalah proses anaerobik sampah organik. Sampah organik berupa sisa sayur sayuran yang diperoleh di pasar tradisional terlebih dahulu dicuci dengan air bersih. Kemudian sayuran tersebut dicacah kecil - kecil hingga ukuran $\pm 5 \mathrm{~cm}$. sayuran tersebut masukkan ke dalam reaktor anaerobik (Gambar2) lalu dicampur dengan larutan starter dan diaduk mereta agar tercampur sempurna. Selanjutnya reaktor tersebut ditutup rapat untuk menghindari udara masuk kedalam reaktor. Proses anaerobik sampah organik dilakukan selama 14 
hari. Pada rentang waktu 2, 4, 6, 8, 10, 12, dan 14 hari dilakukan pengambilan sampel melalui keran bagian bawah reaktor. Analisa $\mathrm{NH}_{4}$ dilakukan menggunakan spectrophotometer Hanna 83300 .

\section{HASIL DAN PEMBAHASAN}

Pengaruh Penambahan EM-4 Terhadap Peningkatan Konsentrasi $\mathrm{NH}_{4}$

Pengaruh variasi EM-4 menjadi faktor penting dalam proses anaerobik dalam memproduksi $\mathrm{NH}_{4}$. Pada Gambar 3 menunjukkan pengaruh variasi EM-4 terhadap proses produksi konsentrasi $\mathrm{NH}_{4}$ pada proses anaerobik. Gambar 3 menunjukkan pengaruh variasi EM-4 dapat meningkatan produksi $\mathrm{NH}_{4}$. Peningkatan produksi $\mathrm{NH}_{4}$ terjadi pada penambahan EM-4 dari 0 sampai $50 \mathrm{ml}$ dan kemudian tidak mengalami pengaruh pada penambahan EM-4 $50 \mathrm{ml}-100 \mathrm{ml}$. Tanpa penambahan EM-4, produksi $\mathrm{NH}_{4}$ dan adalah 447,3 $\mathrm{mg} / \mathrm{L}$ selama proses anaerobik 14 hari. Dan setelah penambahan EM-4 $30 \mathrm{ml}$ terjadi peningkatan produksi $\mathrm{NH}_{4}$ menjadi 605,8 dan kemudian meningkat 2068,5 mg/L pada penambahan EM-4 $50 \mathrm{ml}$ dan setelah penambahan lebih dari $50 \mathrm{ml}$ tidak terjadi peningkatan produksi $\mathrm{NH}_{4}$. Hal ini disebabkan mikroorganisme tidak dapat tumbuh dan berkembangbiak dengan baik karena sumber makanan yang tersedia tidak mencukupi (Mirnawati, 2006).

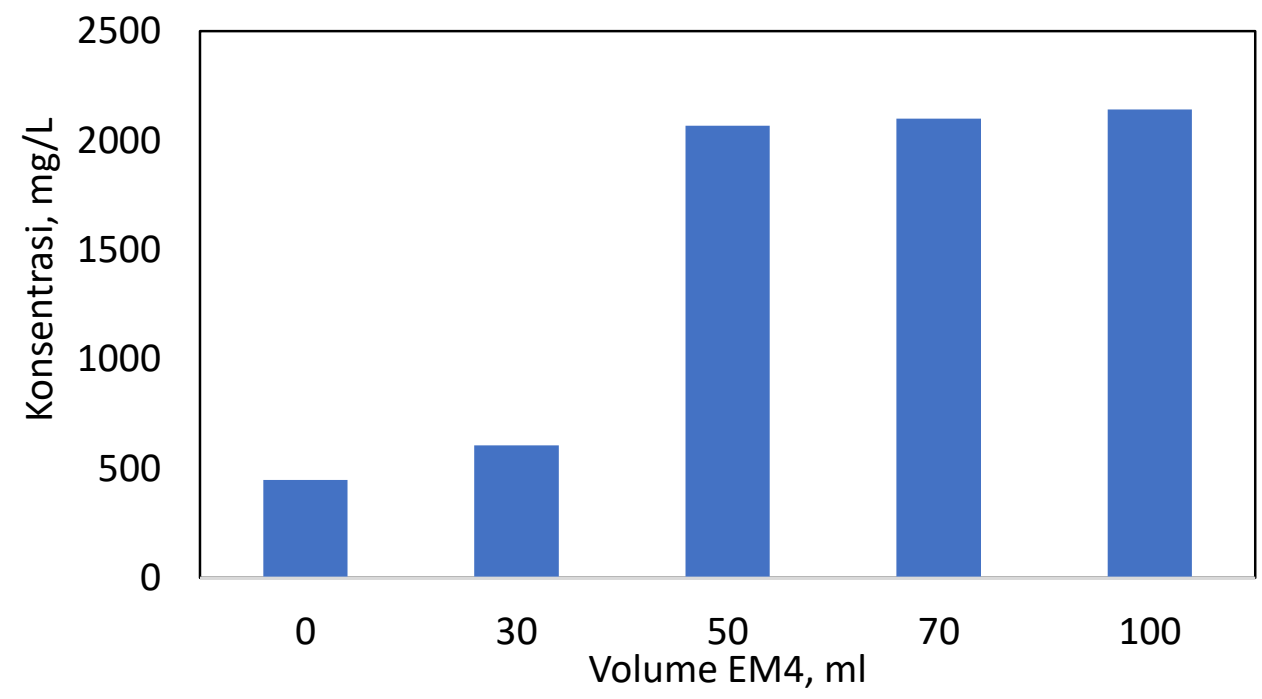

Gambar 3. Pengaruh Penambahan EM-4 terhadap Konsentrasi $\mathrm{NH}_{4}$ dan $\mathrm{PO}_{4}$ selama 14 Hari Proses Anaerobik.

\section{Pengaruh Waktu Proses Anaerobik Terhadap Peningkatan Produksi $\mathrm{NH}_{4}$}

Gambar 4 menunjukkan pengaruh waktu terhadap peningkatan konsentrasi $\mathrm{NH}_{4}$ selama 14 hari proses anaerobik. Hasil penelitian menunjukkan bahwa penambahan EM-4 dapat mempengaruhi yang signifikan konsentrasi $\mathrm{NH}_{4}$ yang dihasilkan selama proses anaerobik sampah organik. Tanpa penambahan EM4 laju peningkatan konsentrasi $\mathrm{NH}_{4}$ terjadi kesetimbangan pada 10 hari proses anaerobik, sedangkan pada penambahan EM-4 $50 \mathrm{ml}$ kesetimbangan terjadi pada hari ke 12. Konsentrasi kesetimbangan $\mathrm{NH}_{4}$ tanpa penambahan EM-4 adalah 655,4 $\mathrm{mg} / \mathrm{L}$ dan 2656,8 $\mathrm{mg} / \mathrm{L}$ pada penambahan EM-4. Kesetimbangan konsentrasi tersebut mengindikasikan 
bahwa ketersediaan nutrisi makanan bagi mikroba sudah tidak tersedia.

Hasil yang sama juga ditunjukkan pada penelitian yang dilakukan oleh Munawaroh (2013) bahwa penambahan EM-4 dapat meningkatkan konsentrasi $\mathrm{NH}_{4}$ pada hari ke 10 namun terjadi penurunan konsentrasi NH4 pada hari ke 20. Penurunan konsentrasi tersebut terjadi sebagai akibat perubahan $\mathrm{NH}_{4}$ menjadi



Gambar 4. Pengaruh Penambahan EM-4 pada Proses Anaerob Pengolahan Sampah Organik terhadap Konsentrasi $\mathrm{NH}_{4}$

Analisa lebih lanjut pada Gambar 4, proses anaerobik dengan penambahan EM-4 pada hari ke 2 terjadi peningkatan konsentrasi hingga 578,2 $\mathrm{mg} / \mathrm{L}$ dan meningkat signifikan hingga 2606,8 mg/L pada hari ke 12. Dan tanpa penambahan EM-4, konsentrasi $\mathrm{NH}_{4}$ pada hari ke 2 adalah 204,6 mg/L kemudian laju peningkatan konsentrasi $\mathrm{NH}_{4}$ tersebut pada hari ke 10 adalah $655,5 \mathrm{mg} / \mathrm{L}$ dan kemudian mencapai kesetabilan. Perbedaan hasil tersebut menunjukkan bahwa penambahan EM-4 dapat meningkatkan jumlah microorganisme yang dapat mendegradasi sampah organik (Nurjuwita et al., 2021).

\section{Kinetika Produksi $\mathrm{NH}_{4}$ pada Proses Anaerobik.}

Studi kinetik dari berguna untuk memprediksi kinerja. perancangan reaktor
NH3 berdasarkan reaksi berikut ini (Möller \& Müller, 2012)

$\mathrm{NH} 4+\mathrm{OH}^{-} \leftrightarrow \mathrm{NH}_{(\mathrm{aq})}+\mathrm{H}_{2} \mathrm{O}$

Ammonia kemudian tersebut berubah menjadi gas seiring dengan peningkatan pH dan temperatur (Krakat, Anjum, Dietz, \& Demirel, 2017). 
$(\mathrm{mg} / \mathrm{L})$. Konsentrasi substrat dapat dikorelasikan dengan produksi $\mathrm{NH}_{4}(\mathrm{~N})$, sebagai berikut:

$\frac{N_{e q}-N}{N_{e q}}=\frac{C}{C_{0}}$.

dimana $N_{\text {eq }}$ adalah produksi $\mathrm{NH}_{4}$ pada keadaan kesetimbangan. Substitusi dari Persamaan. (2) dan (3) didapat persamaan model orde pertama yang memberikan hubungan analitik antara konsentrasi $\mathrm{NH}_{4}$ yang dihasilkan dan waktu proses anaerobik sebagai berikut:

$\ln \frac{N_{e q}-N}{N_{e q}}=k . t$

Nilai $k$ sebagai slop dengan memploting data $\ln \frac{N_{e q}-N}{N_{e q}}$ versus $t$ sehingga menghasilkan garis lurus dengan intersep
0. Hasil plotting data dapat di lihat pada Gambar 5 dengan nilai kesalahan $\mathrm{R}^{2}$ 0,9013 dan 0,9589 . Nilai $R^{2}$ mendekati 1 menunjukkan bahwa degradasi sampah organik terjadi pada kinetika orde pertama. Dari Gambar 5 didapatkan nilai konstanta kinetika $(k)$ adalah 0,0750 hari $^{-1}$ untuk tanpa penambahan EM-4 dan kemudian nilai $k$ meningkat menjadi 0,2396 hari ${ }^{-1}$ dengan penambahan EM-4 sebanyak $50 \mathrm{ml}$. Meningkatnya nilai $k$ pada penambahan EM-4 menunjukkan bahwa dengan penambahan EM-4 dapat meningkatkan laju degradasi sampah organik menjadi $\mathrm{NH}_{4}$. Dan dapat disimpulkan bahwa EM-4 adalah biocatalyst yang baik untuk mendegradasi sampah organik menjadi $\mathrm{NH}_{4}$.



Gambar 5. Perhitungan nilai konstanta kinetika $(k)$

\section{KESIMPULAN}

Pengolahan sampah organik dengan proses anaerobik dengan tanpa maupun penambahan EM4 mampu mendegradasi sampah organik selama 14 hari. Pengaruh variasi penambahan EM-4 dapat meningkatan produksi NH4. Peningkatan produksi $\mathrm{NH}_{4}$ terjadi pada penambahan EM-4 dari 0 sampai $50 \mathrm{ml}$ dan kemudian tidak mengalami pengaruh pada penambahan EM-4 $50 \mathrm{ml}-100 \mathrm{ml}$. Pada

penambahan $50 \mathrm{ml}$ EM-4 konsentrasi $\mathrm{NH}_{4}$ adalah 2068,5 mg/L. Kinetika degradasi sampah organik terjadi pada orde pertama. Nilai $k$ adalah 0,0750 hari $^{-1}$ untuk tanpa penambahan EM-4 dan 0,2396 hari $^{-1}$ dengan penambahan EM-4 sebanyak 50 $\mathrm{ml}$. Nilai konstanta $k$ dapat digunakan untuk memprediksi kinerja, perancangan reaktor dan mekanisme biodegradasi sampah organik dengan proses anaerobik.

\section{DAFTAR PUSTAKA}

Foereid, B., Szocs, J., Patinvoh, R. J., \& Horváth, I. S. (2021). Effect of anaerobic digestion of manure before application to soil - benefor nitrogen 
utilisation? International Journal of Recycling of Organic Waste in Agriculture, 10(1), 89-99. https://doi.org/10.30486/IJROWA.2 020.1897538 .1055

Haerun, R., Mallongi, A., \& Natsir, M. F. (2018). Efisiensi Pengolahan Limbah Cair Industri Tahu Menggunakan Biofilter Sistem Upflow Dengan Penambahan Efektif Mikroorganisme. Jurnal Nasional Ilmu Kesehatan, 1, 1-11.

Hidayat, M. R., Hidayati, \& Utomo, P. P. (2012). Produksi Biogas Dari Limbah Cair Industri Tahu Dengan Biokatalis Effektive Microorganisms 4 (EM-4). Biopropal Industri, 3(1), $1-6$.

Krakat, N., Anjum, R., Dietz, D., \& Demirel, B. (2017). Methods of ammonia removal in anaerobic digestion: A review. Water Science and Technology, 76(8), 1925-1938. https://doi.org/10.2166/wst.2017.40 6

Mirnawati. (2006). Peningkatan Kualitas Limbah Bulu Ayam Melalui Fermentasi dengan Efektif Mikroorganisme 4 (EM4). Jurnal Peternakan Indonesia, 11(3), 242248.

https://doi.org/https://doi.org/10.250 77/jpi.11.3.242-248.2006

Möller, K., \& Müller, T. (2012). Effects of anaerobic digestion on digestate nutrient availability and crop growth: A review. Engineering in Life Sciences, 12(3), 242-257. https://doi.org/10.1002/elsc.2011000 85

Munawaroh, U., Sutisna, M., \& Pharmawati, K. (2013). Penyisihan Parameter Pencemar Lingkungan pada Limbah Cair Industri Tahu
Menggunakan Efektif

Mikroorganisme 4 (EM4) Serta

Pemanfaatannya. Jurnal Institut Teknologi Nasional, 1(2), 93-104.

Nurjuwita, W., Sasongko, A., Hartanto, T. J., \& Purwanto, M. (2021). Potential and characterization biogas from tofu liquid waste with addition cow dung and effective microorganisms 4 as biocatalyst. Materials Today: Proceedings, 46, 1908-1912. https://doi.org/10.1016/j.matpr.2021. 02.025

Prayitno, P., Rulianah, S., \& Nurmahdi, H. (2020). Pembuatan Biogas Dari Limbah Cair Tahu Menggunakan Bakteri Indigeneous. Jurnal Teknik Kimia Dan Lingkungan, 4(2), 90-95. https://doi.org/10.33795/jtkl.v4i2.14 1

Sajeena Beevi, B., Madhu, G., \& Sahoo, D. K. (2015). Performance and kinetic study of semi-dry thermophilic anaerobic digestion of organic fraction of municipal solid waste. Waste Management, 36, 9397.

https://doi.org/10.1016/j.wasman.20 14.09.024

Siswati, N. D., Theodorus, H., \& Eko, W. (2009). Kajian Penambahan Effective Microorganisms (EM4) Pada Proses Dekomposisi Limbah Padat Industri Kertas. Jurnal Buana Sains, 9(1), 63-68.

Sogn, T. A., Dragicevic, I., Linjordet, R., Krogstad, T., Eijsink, V. G. H., \& Eich-Greatorex, S. (2018). Recycling of biogas digestates in plant production: NPK fertilizer value and risk of leaching. International Journal of Recycling of Organic Waste in Agriculture, 7(1), 49-58. https://doi.org/10.1007/s40093-0170188-0 
Pengaruh Penambahan Effective Microorganisms-4...,Eko Ariyanto, Shanti Mayasari, Dian Kharismadewi, Indobiosains, Volume 4 No.1, Februari 2022, 28-35.

Sumantri, I., \& Hadiyanto, H. (2020). Kinetic of biogas production in a batch anaerobic digestion process with interference of preservative material of sodium benzoate. Bulletin of Chemical Reaction Engineering \& Catalysis, 15(3), 898-906. https://doi.org/10.9767/BCREC.15.3 .9366.898-906 